\title{
Gambaran Faktor - Faktor yang Menyebabkan Remaja Putri Untuk Merokok
}

\author{
Dessy Lestari \\ Psikologi, Fakultas Ilmu Pendidikan, Universitas Negeri Jakarta \\ Jalan Rawamangun Muka 13220, Jakarta Timur
}

Email: $\underline{\text { abcdesy@rocketmail.com }}$

\begin{abstract}
The purpose of this research is to give a representation about teenage girls cigarette smoking factor in Jakarta.

Sample for this research are 61 teenage girls with different characteristics age range 1518 years, smoking and live in Jakarta. Data collection technique is non-probability sampling technique with accidental sampling. The research design used by the writer is descriptive statistical analysis.

According to the results obtained from the respondents, of the three dimentions that can lead teenage girls smoking is peer influence, family influence, and self - image of smokers showed that the three dimentions there are no dimention are very striking as a cause of teenage girls smoking, but from the third dimentions of peer influence reached the highest score compared with the other two dimentions with the percentage of $35 \%$.
\end{abstract}

\section{Keywords: The factors that cause smoking, Teenage girls}

\section{Pendahuluan}

Merokok merupakan salah satu fenomena gaya hidup pada kebanyakan orang saat ini. Setiap perokok memiliki alasan yang berbeda mengapa mereka merokok, ada yang merasa lebih bebas, dapat mengalihkan pikiran, menghilangkan stress, memperbaiki memori, mengurangi kecemasan, memperbaiki konsentrasi dan bisa pula orang merokok sebagai ekspresi perlawanan dan pemberontakan (Stefanus, 2002, p.71). Para perokok memiliki alasan yang menguntungkan bagi dirinya, namun tidak ada yang memungkiri bahwa adanya dampak negatif dari perilaku merokok, namun para perokok tetap saja tidak peduli apabila diingatkan terhadap ancaman yang setiap saat akan dapat menyiksanya dalam waktu lama dan bahkan dapat merenggut nyawanya. Tidak mengherankan jika saat ini merokok seakan telah menjadi gaya hidup. Ironisnya, gaya hidup ini telah merambah usia muda, yakni remaja.

Berdasarkan data World Health Organization (WHO), sekitar 20 persen dari satu milyar perokok di dunia adalah wanita, tujuh persen remaja perempuan dan 12 persen remaja laki-laki perokok di 151 negara di dunia aktif merokok. Jumlah tersebut akan terus meningkat jika tidak diwaspadai. Di Indonesia, Data Rumah Sakit Persahabatan, Jakarta, menunjukkan 4 
persen perokok berasal dari remaja putri. Remaja perempuan yang masih duduk di kursi sekolah menengah pertama merokok berjumlah 11,5 persen. Angka prevalensi perokok perempuan di Indonesia mencapai 4,83 persen. Sementara, data prevalensi perokok Lembaga Demografi Universitas Indonesia 2008, menunjukkan delapan persen perokok dari total perokok di Jakarta adalah perempuan. Perokok aktif perempuan paham dan mengetahui resiko dari perilaku merokoknya tersebut. Banyak hal yang merugikan, terutama bagi kesehatan. Merokok bagi seorang perempuan yaitu merokok dapat mengurangi sekresi estrogen yang diduga bertanggung jawab atas gangguan menstruasi termasuk timbulnya rasa nyeri. Merokok juga bisa menyebabkan perubahan nada suara dan peningkatan bulu tubuh dan juga menopause terjadi 1 sampai 2 tahun lebih awal di kalangan perokok perempuan.

Sudah cukup jelasnya pengaruh negatif ataupun akibat dari rokok namun masih banyak alasan yang melatarbelakangi remaja untuk merokok. Secara umum berdasarkan kajian Kurt Lewin (dalam Komalasari, 2002, p.2), merokok merupakan fungsi dari lingkungan dan individu. Artinya, perilaku merokok selain disebabkan dari faktor lingkungan juga disebabkan oleh faktor diri atau kepribadian. Faktor lingkungan dapat disebabkan karena orang tua atau teman sebaya yang merokok. Ketika orang - orang terdekatnya merupakan perokok aktif, maka remaja akan lebih mudah untuk memulai merokok, karena orang tua atau teman sudah menjadi modeling bagi remaja tersebut. Faktor dalam diri remaja dapat dilihat dari kajian perkembangan remaja. Remaja mulai merokok dikatakan oleh Erikson (dalam Komalasari, 2002, p.2) berkaitan dengan adanya krisis aspek psikososial yang dialami pada masa perkembangannya yaitu masa ketika mencari jati diri. Dalam masa pencarian jati diri remaja ini sering terjadi ketidaksesuaian antara perkembangan psikis dan perkembangan sosial. Upaya-upaya untuk menemukan jati diri tersebut tidak selalu dapat berjalan sesuai dengan harapan masyarakat. Beberapa remaja melakukan perilaku merokok sebagai cara kompensatoris, dengan kata lain perilaku merokok bagi remaja merupakan perilaku simbolisasi, simbol dari kematangan, kekuatan, kepemimpinan, dan daya tarik terhadap lawan jenis.
Egosentrisme remaja juga disebut sebagai satu hal yang mempengaruhi remaja merokok. Remaja akan semakin peduli pada penampilan mereka dalam pandangan orang lain sehingga remaja memiliki kebutuhan untuk menunjukan citra diri yang positif kepada orang lain. Citra diri perokok adalah faktor yang berpengaruh pada perilaku mulai merokok. Remaja telah mengidentifikasi merokok dengan kejantanan, kebebasan, ketampanan, pergaulan, daya tarik seksual, kesejahteraan dan kehidupan yang baik (Rice, 2001, p.436). Apabila citra diri ideal remaja mirip dengan citra tipikal perokok, maka remaja akan cenderung merokok. Hal lain yang mendorong remaja untuk mulai merokok juga berhubungan dengan kebutuhan status dan harga diri (Rice, 2001, p.437). Adanya anggapan keliru yang dipahami para remaja yakni dengan merokok, remaja merasa gaul, macho, sehingga timbul rasa percaya diri. Berdasarkan penjelasan di atas, terlihat bahwa perilaku merokok pada remaja berhubungan dengan kebutuhan untuk memiliki citra diri yang ideal yang berasal dari faktor dalam diri dan faktor lingkungan, keduanya membantu untuk meningkatkan harga diri remaja. Seringkali remaja merokok sebagai kompensasi ketertinggalan mereka dibanding teman sebaya disekolah, karena mereka tidak berpartisipasi dalam kegiatan ekstrakulikuler, atau karena mereka tidak mempunyai kebutuhan ego lain yang ingin mereka puaskan.

Dari faktor - faktor yang menyebabkan remaja putri merokok dan juga fakta diatas yang ditemukan dilapangan, maka peneliti ingin melakukan penelitian lebih lanjut mengenai faktor faktor yang menyebabkan remaja putri merokok di Jakarta.

\section{Metode Penelitian}

\section{a. Definisi Operasional variabel penelitian}

Definisi operasional faktor - faktor yang mempengaruhi remaja merokok didalam penelitian ini adalah skor total dari kuesioner faktor-faktor yang mempengaruhi remaja putri merokok serta hasil coding dari pertanyaan terbuka yang terkait dengan faktor - faktor remaja putri merokok. 


\section{b. Subjek Penelitian}

Sebagai sumber data penelitian ini adalah remaja putri yang berada di daerah Jakarta dengan rentang usia $15-18$ tahun yang merupakan perokok aktif. Dalam penelitian ini melibatkan 61 remaja putri perokok aktif yang berada di Jakarta.

\section{c. Alat Pengukuran Data}

Pada penelitian ini, metode penelitian yang digunakan adalah metode survey. Metode survey digunakan untuk mendapatkan data dari tempat tertentu yang alamiah (dalam arti responden tidak diberikan perlakuan), tetapi peneliti melakukan dalam bentuk penggunaan instrument penelitian untuk mengumpulkan data (Sugiyono, 2008, p.199).

Pada penelitian ini alat pengumpulan data yang digunakan adalah kuesioner. Kuesioner merupakan salah satu jenis alat pengumpulan data berupa sejumlah daftar pertanyaan atau pernyataan tertulis yang disampaikan kepada responden atau partisipan penelitian.

Peneliti menggunakan skala yang dibuat sendiri yang terdiri dari tiga dimensi seperti berikut:

Tabel 1. Dimensi Faktor - Faktor Remaja Merokok

\begin{tabular}{ccc}
\hline Dimensi & Indikator \\
\hline Teman sebaya & 1. & $\begin{array}{c}\text { Mengalami konformitas dalam kelompok } \\
\text { Mengalami tekanan dalam kelompok }\end{array}$ \\
\hline Keluarga & 1. & $\begin{array}{c}\text { Memiliki anggota keluarga yang merokok } \\
\text { Cemiliki masalah yang ada dalam keluarga }\end{array}$ \\
\hline Citra diri & 1. & Merasakan image positif menjadi perokok \\
& 2. & Bertujuan untuk menutupi kekurangan diri
\end{tabular}

Uji coba alat ukur data dilakukan kepada 60 remaja putri merokok di Jakarta. Hasil uji validitas dan reliabilitas terhadap skala tersebut terlihat dalam tabel berikut:

Tabel 2. Hasil Uji Validitas dan Reliabilitas

\begin{tabular}{cccc}
\hline Jenis Skala & Jumlah Aitem & Aitem Valid & Koefisien Reliabilitas \\
\hline $\begin{array}{c}\text { Faktor Remaja Putri } \\
\text { Merokok }\end{array}$ & 40 & 35 & 0.902 \\
\hline
\end{tabular}

\section{d. Teknik Analisis Data}

Penelitian ini menggunakan analisis deskriptif. Analisis deskriptif digunakan untuk melakukan analisis suatu kumpulan data sehingga kumpulan data tersebut dapat memberikan suatu informasi tertentu. Dalam penelitian ini peneliti penggunakan perangkat SPSS versi 17.0 untuk mencari hasil perhitungan. 


\section{Hasil dan Diskusi}

Berikut ini akan disajikan hasil uji data secara deskriptif seperti terlihat pada tabel 2.

\begin{tabular}{lccccccc}
\hline Dimensi & Maksimum & Minimum & Mean & Median & Modus & SD & Range \\
\hline $\begin{array}{c}\text { Pengaruh } \\
\text { Teman } \\
\text { sebaya }\end{array}$ & 31 & 12 & 24.20 & 25.00 & 26 & 3.4 & 19 \\
$\begin{array}{l}\text { Pengaruh } \\
\text { Keluarga }\end{array}$ & 33 & 14 & 25.61 & 26.00 & 27 & 4.1 & 19 \\
Citra Diri & 57 & 32 & 45.72 & 46.00 & 46 & 5.3 & 25 \\
\hline
\end{tabular}

Setelah mendapatkan skala final, skala diisi oleh 61 remaja putri merokok yang berada dijakarta, setelah dilakukan perhitungan, didapatkan hasil seperti dibawah ini.

Tabel 3. Hasil Perhitungan Tiga Dimensi

\begin{tabular}{cccc}
\hline Dimensi & Jumlah Aitem & Total Skor & Presentase \\
\hline Pengaruh Teman & 8 & 184,36 & $35 \%$ \\
sebaya & & & \\
Pengaruh Keluarga & 10 & 170,4 & $33 \%$ \\
Citra Diri & 17 & 163,78 & $32 \%$ \\
\hline Total & $\mathbf{3 5}$ & $\mathbf{5 1 8 . 5 4}$ & $\mathbf{1 0 0 \%}$ \\
\hline
\end{tabular}

Berdasarkan hasil data yang diperoleh dari responden, didapatkan bahwa dari ketiga dimensi tersebut tidak memiliki selisih yang cukup jauh sebagai faktor yang dapat menyebabkan remaja putri untuk merokok, namun untuk dimensi pengaruh teman sebaya merupakan dimensi yang paling tinggi perolehannya sebagai dimensi yang dapat menyebabkan remaja putri merokok yaitu dengan total skor sebesar 184,36.

Tabel 4. Hasil Perhitungan Per Indikator dari Tiga Dimensi

\begin{tabular}{|c|c|c|}
\hline Indikator & Total Skor & Presentase \\
\hline $\begin{array}{c}\text { Mengalami konformitas dalam } \\
\text { kelompok }\end{array}$ & 201.5 & $20 \%$ \\
\hline Mengalami tekanan dalam kelompok & 167.5 & $16 \%$ \\
\hline $\begin{array}{l}\text { Memiliki anggota keluarga yang } \\
\text { merokok }\end{array}$ & 141.5 & $14 \%$ \\
\hline $\begin{array}{l}\text { Memiliki masalah yang ada dalam } \\
\text { keluarga } \\
\text { Merasakan Image positif menjadi } \\
\text { perokok }\end{array}$ & 189.51 & $19 \%$ \\
\hline $\begin{array}{l}\text { Bertujuan untuk menutupi } \\
\text { kekurangan diri }\end{array}$ & 182.8 & $18 \%$ \\
\hline Total & 1019.82 & $100 \%$ \\
\hline
\end{tabular}


Selain menggunakan skala dengan terdapat juga pertanyaan terbuka yang diberikan kepada responden dengan hasil sebagai berikut:

Deskripsi data dibawah ini menyajikan data hasil coding pada pertanyaan pertama yaitu "sejak kapan kamu merokok?"

Tabel 5. Hasil Coding Pertanyaan 1

\begin{tabular}{cccc}
\hline No & Jawaban & Frekuensi & Persentase \\
\hline 1. & 12 Tahun & 2 & $3 \%$ \\
2. & 13 Tahun & 1 & $2 \%$ \\
3. & 14 Tahun & 16 & $26 \%$ \\
4. & 15 Tahun & 11 & $18 \%$ \\
5. & 16 Tahun & 18 & $30 \%$ \\
6. & 17 Tahun & 13 & $21 \%$ \\
\hline & Jumlah & 61 & $100 \%$ \\
\hline
\end{tabular}

Deskripsi data dibawah ini menyajikan data hasil coding pada pertanyaan kedua yaitu "apa yang menyebabkan kamu merokok pada saat itu?"

Tabel 6. Hasil Coding Pertanyaan 2

\begin{tabular}{cccc}
\hline No & Jawaban & Frekuensi & Persentase \\
\hline 1. & Masalah keluarga & 7 & $11 \%$ \\
2. & Masalah pribadi & 20 & $33 \%$ \\
3. & Mencoba - coba & 19 & $31 \%$ \\
4. & Terpengaruh teman & 15 & $25 \%$ \\
\hline & Jumlah & 61 & $100 \%$ \\
\hline
\end{tabular}

Deskripsi data dibawah ini menyajikan data hasil coding pada pertanyaan ketiga yaitu " berapa batang rokok yang biasanya kamu hisap?"

Tabel 7. Hasil Coding Pertanyaan 3

\begin{tabular}{cccc}
\hline No & Jawaban & Frekuensi & Presentase \\
\hline 1. & $1-8$ batang & 41 & $67 \%$ \\
2. & 12 batang & 17 & $28 \%$ \\
3. & Kalau mau saja & 3 & $5 \%$ \\
\hline & Jumlah & $\mathbf{6 1}$ & $\mathbf{1 0 0 \%}$ \\
\hline
\end{tabular}

Deskripsi data dibawah ini menyajikan data hasil coding pada pertanyaan kelima yaitu "apakah orang tua mengetahui bahwa kamu merokok?"

Tabel 8. Hasil Coding Pertanyaan 5

\begin{tabular}{cccc}
\hline No & Jawaban & Frekuensi & Presentase \\
\hline 1. & Mengetahui & 18 & $29 \%$ \\
2. & Tidak Mengetahui & 42 & $69 \%$ \\
3. & Mungkin Tahu & 1 & $2 \%$ \\
\hline & Jumlah & 61 & $100 \%$ \\
\hline
\end{tabular}

Deskripsi data dibawah ini menyajikan data hasil coding pada pertanyaan keenam yaitu "apa yang akan kamu lakukan bila orang tua mengetahui bahwa kamu merokok?" 
Tabel 9. Hasil Coding Pertanyaan 6

\begin{tabular}{cccc}
\hline No & Jawaban & Frekuensi & Presentase \\
\hline 1. & Diam & 28 & $46 \%$ \\
2. & Menjelaskan & 5 & $8 \%$ \\
3. & Biasa saja & 13 & $21 \%$ \\
4. & Mencoba berhenti & 1 & $2 \%$ \\
5. & Minta maaf & 4 & $7 \%$ \\
6. & Menangis & 2 & $3 \%$ \\
7. & Jawaban tidak sesuai & 8 & $13 \%$ \\
\hline & Jumlah & 61 & $100 \%$ \\
\hline
\end{tabular}

Deskripsi data dibawah ini menyajikan data hasil coding pada pertanyaan ketujuh yaitu "menurut kamu, apa yang akan orang tua kamu lakukan bila mengetahui bahwa kamu merokok?"

Tabel 10. Hasil Coding Pertanyaan 7

\begin{tabular}{cccc}
\hline No & Jawaban & Frekuensi & Presentase \\
\hline 1. & Menegur & 9 & $15 \%$ \\
2. & Marah & 45 & $74 \%$ \\
3. & Menasehati & 4 & $6 \%$ \\
4. & Tidak Tahu & 3 & $5 \%$ \\
\hline & Jumlah & 61 & $100 \%$ \\
\hline
\end{tabular}

Deskripsi data dibawah ini menyajikan data hasil coding pada pertanyaan terakhir yaitu "bagaimana pandangan kamu terhadap remaja putri yang merokok

Tabel 11. Hasil Coding Pertanyaan 8

\begin{tabular}{cccc}
\hline No & Jawaban & Frekuensi & Presentase \\
\hline 1. & Bandel & 1 & $2 \%$ \\
2. & Kurang baik & 10 & $16 \%$ \\
3. & Ironis & 1 & $2 \%$ \\
4. & Biasa saja & 39 & $64 \%$ \\
5. & Keren & 2 & $3 \%$ \\
6. & Merokok pasti ada & 8 & $13 \%$ \\
& alasannya & & $\mathbf{1 0 0 \%}$ \\
\hline
\end{tabular}

Dari hasil penelitian, remaja putri merokok yang berada pada kategori tinggi menggambarkan bahwa dimensi dari faktor remaja merokok cukup sesuai dengan kondisi yang responden alami. Ketiga dimensi tersebut adalah pengaruh teman sebaya yang terdiri dari dua indikator yaitu konformitas dalam kelompok dan tekanan dalam kelompok . Dimensi kedua yaitu pengaruh keluarga, dimensi tersebut dibagi menjadi dua indikator yaitu anggota keluarga yang merokok dan masalah yang ada dalam keluarga. Dimensi terakhir yaitu citra diri yang terbagi menjadi dua indikator yaitu Image positif menjadi perokok dan menutupi kekurangan diri.
Dari keseluruhan hasil data yang diperoleh dari responden, didapatkan bahwa dari enam indikator yang berasal dari tiga dimensi tersebut tidak memiliki selisih yang cukup jauh sebagai faktor yang dapat menyebabkan remaja putri untuk merokok, namun untuk indikator mengalami konformitas dalam kelompok merupakan indikator yang paling tinggi perolehannya sebagai indikator yang dapat menyebabkan remaja putri merokok yaitu dengan presentase $20 \%$.

Berdasarkan hasil yang diperoleh dari responden, maka didapatkan bahwa dimensi pengaruh teman sebaya merupakan faktor yang paling menyebabkan remaja putri untuk merokok di Jakarta. Hasil 
tersebut diperoleh dari hasil perhitungan yang dilakukan oleh peneliti yaitu jumlah hasil persebaran jawaban responden setiap dimensi dibagi oleh jumlah aitem masing masing dimensi. Dari hasil perhitungan tersebut didapatkan bahwah pengaruh teman sebaya memperoleh total skor sebesar 184.36 dengan presentase sebesar 35\%, pengaruh keluarga mendapat total skor sebesar 170.4 dengan presentase sebesar $33 \%$ dan dimensi citra diri memperoleh total skor sebesar 163,78 dengan presentase $32 \%$

Hasil yang diperoleh diatas sesuai dengan yang dikemukakan oleh Rice (2001) yaitu remaja mulai merokok karena tekanan teman sebaya. Bahkan suatu penelitian menunjukan walaupun orang tua tidak merokok namun remaja memiliki teman sebaya yang merokok maka mempunyai pengaruh pada perilaku mulai merokok sejak remaja awal. Adanya anggapan bahwa remaja yang melakukan kebiasaan orang dewasa sebelum pada waktunya akan lebih dikagumi dibanding teman - teman yang lainnya.

Menurut hasil yang diperoleh yaitu remaja putri akan cenderung merokok apabila mendapatkan pengaruh dari teman sebayanya. Berdasarkan hasil penelitian jangka panjang (Chassin, Presson, Sherman, 1990; Edwards; Muray, Swan, Johnson, \& Bewley, dalam Sarafino, 2006) mengenai peran psikososial dalam perkembangan merokok menunjukan bahwa merokok cenderung diteruskan atau ditingkatkan jika remaja merasa mendapat tekanan dari teman sebaya untuk merokok. adanya laporan "orang lain akan mengejek kamu jika kamu tidak merokok" dan "kamu harus merokok jika sedang bersama dengan teman - teman yang merokok". Teman sebaya memang memiliki banyak pengaruh terhadap diri remaja karena waktu dan kegiatan diluar rumah lebih banyak bersama dengan teman sebaya dibandingkan untuk sekedar sharing dirumah bersama dengan keluarga, terlebih pada masa remaja seorang remaja merasa dirinya sudah mandiri, sehingga merasa bahwa kurang perlu untuk berbagi cerita atau masalah kepada orang tua karena pada saat remaja tersebut seseorang akan lebih membutuhkan teman untuk berbagi cerita. Dari hasil data demografi didapatkan bahwa mayoritas dari responden merokok tanpa sepengetahuan dari orang tua mereka, terlihat disini ada suatu ketakutan dari responden untuk berterus terang mengenai perilaku merokok tersebut karena dari jawaban pada pertanyaan terbuka lainnya, remaja putri sudah memiliki bayangan apa yang akan dilakukan oleh orang tuanya apabila mengetahui bahwa anak putrinya merokok, mayoritas responden menjawab orang tua mereka akan marah terhadap dirinya. Namun tampaknya ketakutan tersebut tidak mempengaruhi keinganan responden untuk berhenti merokok, sebab remaja putri merokok yang menjadi responden beranggapan bahwa saat ini sudah tidak masalah apabila remaja putri merokok, sudah hal yang wajar dan biasa saja karena responden merasa itu merupakan hak dari setiap individu.

Dari hasil penelitian yaitu remaja putri perlu menemukan solusi ataupun kompensasi yang lebih positif apabila sedang menghadapi masalah yang mereka anggap berat. Tidak hanya pengaruh yang berasal dari luar yaitu pengaruh teman dan pengaruh keluarga, namun pengaruh yang berasal dari dalam diri pun sangat berpengaruhi keputusan remaja putri untuk merokok.

Lingkungan keluarga dan teman sepermainan juga menjadi alasan bagi remaja putri yang merokok. Ketidaknyamanan yang didapatkan dalam lingkungan keluarga dan lingkungan pertemanan dapat mengakibatkan remaja putri yang awalnya tidak merokok menjadi merokok. Ketidakstabilan emosi mengantarkan remaja putri menjadi perokok karena mereka merasa bahwa dengan merokok dapat mengurangi beban ataupun melupakan hal yang memang tidak mereka harapkan. Oleh karena itu bagi keluarga dan teman sepermainan sangat diharapkan agar dapat menciptakan suasana yang kondusif dan juga nyaman agar remaja putri tersebut tidak terbebani dengan hal - hal negatif yang berasal dari keluarga ataupun teman.

Meskipun berdasarkan data yang diperoleh dari responden penelitian, hasil yang tertinggi yaitu pengaruh teman sebaya, bukan berarti dimensi yang lain ditidak berpengaruh. Dimensi pengaruh keluarga dan citra diri juga dapat menjadi penyebab dari remaja putri merokok namun memang bukan alasan utama bagi remaja putri yang merokok. Bila dilihat dari hasil data demografi bahwa masalah pribadi menjadi jawaban mayoritas remaja sebagai alasan awal mengapa mereka merokok. Masalah pribadi tersebut sesuai dengan dimensi citra diri, karena citra diri tersebut lebih kepada 
bagaimana penilian responden terhadap diri mereka sendiri.

\section{Kesimpulan}

Berdasarkan data yang diperoleh dari responden, dari ketiga dimensi faktor faktor yang menyebabkan remaja putri untuk merokok berasal dari faktor dimensi ekstrinsik yaitu pengaruh teman sebaya dan pengaruh keluarga serta dimensi intrinsik yaitu citra diri. Penelitian tersebut menunjukan hasil bahwa ketiga dimensi tersebut tidak ada yang sangat mencolok sebagai penyebab remaja putri merokok, namun dari ketiga dimensi tersebut pengaruh teman sebaya memperoleh skor tertinggi dibandingkan dua dimensi yang lainnya dengan presentase sebesar 35\%.

\section{Daftar Pustaka}

Creswell. John W. (2010). Research Design Pendekatan kualitatif, Kuantitatif, dan Mixed. Yogyakarta. Pustaka Pelajar

Hurlock, B.Elizabeth. (1999). Psikologi Perkembangan: Suatu Pendekatan Sepanjang Rentang Kehidupan. Terjemahan oleh Istidawanti \& Soedjarwo. Jakarta: Erlangga.

Kaplan, R.M.,Salis, J.F., Patterson, T.L. (1993). Health and Human Behavior. New York: McGraw-Hill, Inc

Komalasari, Dian \& Helmi, Avin Fadilla. (2000). Faktor-Faktor Penyebab Perilaku Merokok Pada Remaja. Jurnal Psikologi, 28: 37-47.

Loureiro, Maria L et all. Smoking Habits: Like Father, Like Son,Like Mother, Like Daughter. Germany. IZA

Maggi S, Hertzman C, and Vaillancourt T. "Changes in smoking behaviours from late childhood to adolescence: Insights from the Canadian National Longitudinal Survey of Children and Youth." Health Psychology 26(2) (2007)

McIlveen, Rob \& Gross, Richard. (1997). Developmental Psychology. London: Hodder\&Stoughton
Oskam. Stuart \& Schultz, P. Wesley. (1998). Applied Social Psychology $2^{\text {nd }}$ edition. New Jersey: PrenticeHall, Inc

Raharjo, Budi. Jumlah Perokok Wanita Bertambah Pesat, (online), (http://www.republika.co.id/berita/br eakingnews/nasional/10/05/31/117775jumlah-perokok-wanita-bertambahpesat ,diakses pada 21 Desember 2011, 20.13)

Rice. F Philip. (2001). The Adolescent Development, Relationship, and Culture. London:. Pearson

Rossi, Indra Manenda. Perokok Remaja Indonesia Tertinggi Di Dunia, (online)

(http://www.tempo.co/read/news/200 6/06/01/05578242/Perokok-RemajaIndonesia-Tertinggi-di-Dunia ,diakses pada 25 Desember 2011, 13.03)

Sarafino, E.P. (2006). Health Psychology Biopsychosocial Interactions $5^{\text {th }}$ Edition. New Jersey : John Willey and Sons

Sitepoe, Mangku. (2000). Kekhususan Rokok Indonesia. Jakarta: PT Gramedia Widiasarana

Smet, B. (1994). Psikologi Kesehatan. Semarang: PT Gramedia

Snow, P.C,. Bruce, D.D. (2003). Cigarette smoking in teenage girls: exploring the role of peer reputations, selfconcept and coping. Health education research. Oxford University Press
SSDC. (2000). Understanding Smoking Behavior, (online), (http://ssdc.ucsd.edu/ tobacco/reports/Chap3.pdf, diakses 3 Maret 2009).

Taylor, Shelley E. (2008). Health Psychology (7thed). New York: McGraw Hill

Wika, Angela. Merokok resiko lebih besar pada perempuan , (online), 
Jurnal Penelitian dan Pengukuran Psikologi

Vol. 1, No.1, Oktober 2012

(http://www.ayahbunda.co.id/Berita.

Ayahbunda/Info+keluarga/merokok.ri

siko.lebih.besar.pada.perempuan/002/

$002 / 52 / 35 /-/ 4 / \mathrm{c}$. , diakses pada 21

Desember 2011)

Wulandari. Devi. (2005). Adolescents Smoking Behavior. Determinants of Smoking In Indonesia Adolescents.

Jakarta: Universitas Paramadina 